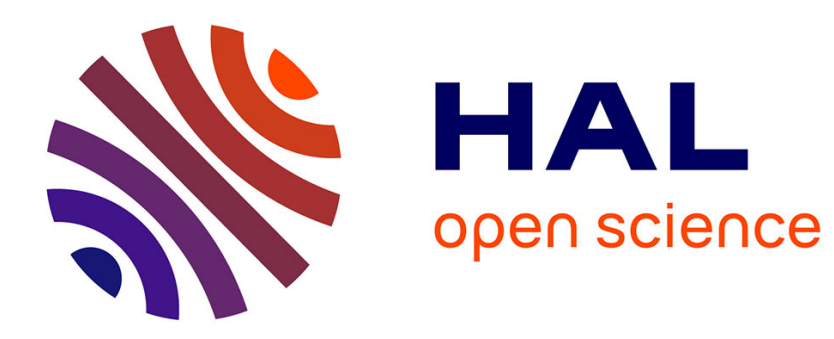

\title{
The nuclear structure facility at Daresbury Laboratory
}

R.G.P. Voss

\section{To cite this version:}

R.G.P. Voss. The nuclear structure facility at Daresbury Laboratory. Revue de Physique Appliquée, 1977, 12 (10), pp.1347-1352. 10.1051/rphysap:0197700120100134700 . jpa-00244323

\section{HAL Id: jpa-00244323 https://hal.science/jpa-00244323}

Submitted on 1 Jan 1977

HAL is a multi-disciplinary open access archive for the deposit and dissemination of scientific research documents, whether they are published or not. The documents may come from teaching and research institutions in France or abroad, or from public or private research centers.
L'archive ouverte pluridisciplinaire HAL, est destinée au dépôt et à la diffusion de documents scientifiques de niveau recherche, publiés ou non, émanant des établissements d'enseignement et de recherche français ou étrangers, des laboratoires publics ou privés. 


\title{
THE NUCLEAR STRUCTURE FACILITY AT DARESBURY LABORATORY
}

\author{
R. G. P. VOSS
}

Daresbury Laboratory, Science Research Council, Daresbury, Warrington WA4 4AD, England

\begin{abstract}
Résumé. - Un accélérateur électrostatique tandem pour ions de toutes sortes, y compris les ions lourds, est en construction au Laboratoire de Daresbury. Le projet est bien avancé, et un effort considérable continue d'être consacré à un programme de recherche et de développement dans la technologie des accélérateurs électrostatiques.
\end{abstract}

Abstract. - A $30 \mathrm{MV}$ tandem electrostatic accelerator for ions of all types, including heavy ions, is being built at Daresbury Laboratory. Construction is well advanced, and considerable effort is continuing to be devoted to an R. \& D. programme into the technology of electrostatic accelerators.

At the time of the first conference in this series, at Daresbury in May 1973, the design study for the Nuclear Structure Facility (NSF) had been completed and preparations were being made for a public inquiry to decide whether planning permission for the buildings should be approved. This was obtained at the end of the year and in January 1974 full financial authorisation was given.

Since that time considerable progress has been made, and the present situation will be reviewed in this paper. In figure 1 are shown the two towers and the associated buildings. The building and civil work has been subject to considerable delays, which in turn have caused the overall timescale for the facility to be put back by a number of months. However, work is now progressing fairly well. The injector room should be complete with all services by the end of the year, the 3 experimental areas are complete apart from some problems with the overhead cranes, and in the remainder of the building the installation of mechanical and electrical services is well advanced.

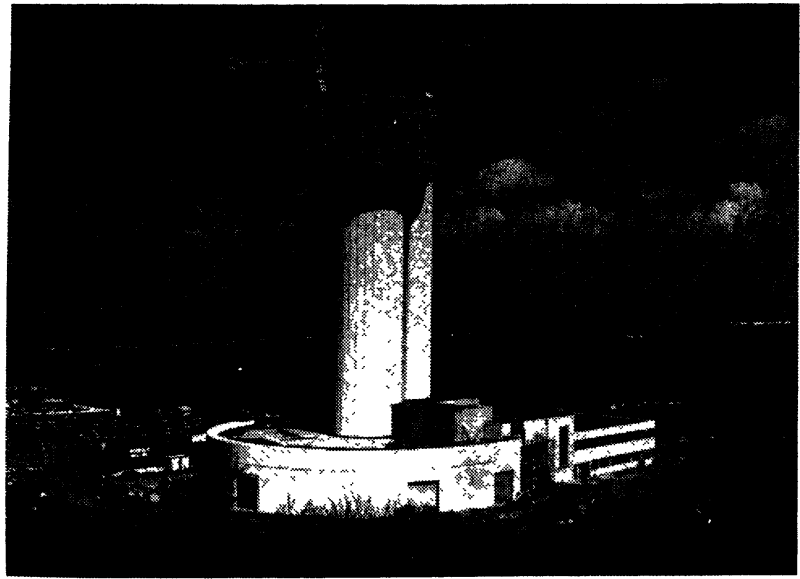

FIG. 1. - Photograph of 2 towers and buildings.
The pressure vessel, $45 \mathrm{~m}$ high and $8.2 \mathrm{~m}$ in diameter and weighing 280 tonnes, has been assembled in the main tower and tested hydraulically to 8.5 atmospheres with 2000 tonnes of water. The base grid which will carry the accelerator column has been installed. The sulphur hexafluoride gas handling plant is all on site, and much of it has been installed: the 3 liquid storage vessels, compressors, vacuum pumps, heat exchangers, etc.

Most of the components for column construction are ready. Assembly of the column was delayed by the

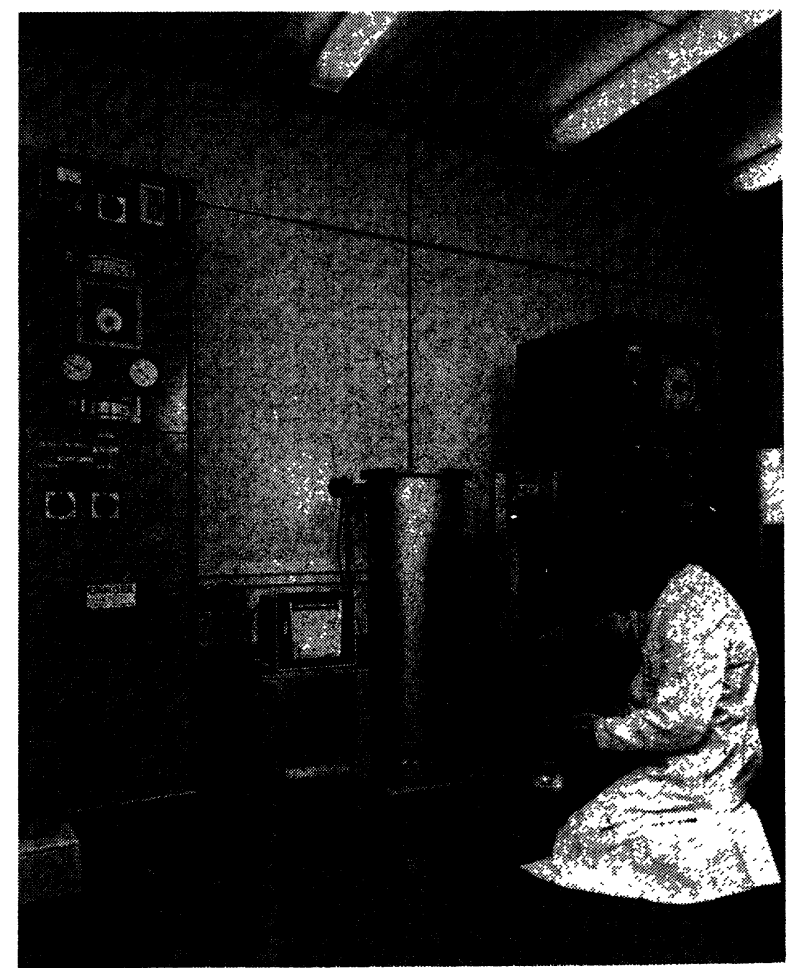

FIG. 2. - Photograph of stack leg manufacture 
building programme, but is now in progress in one of the experimental areas. Figure 2 shows part of the production line in the Laboratory for manufacturing the stack legs: about 200 of the 288 needed are now complete. Figure 3 shows details of the column layout. All the bulkhead rings are complete, and all the alternators have been delivered. Unfortunately the latter require some remedial work. The laddertron and the drive shaft are complete and extensively tested in a special rig built in a tall building. Figure 4 shows

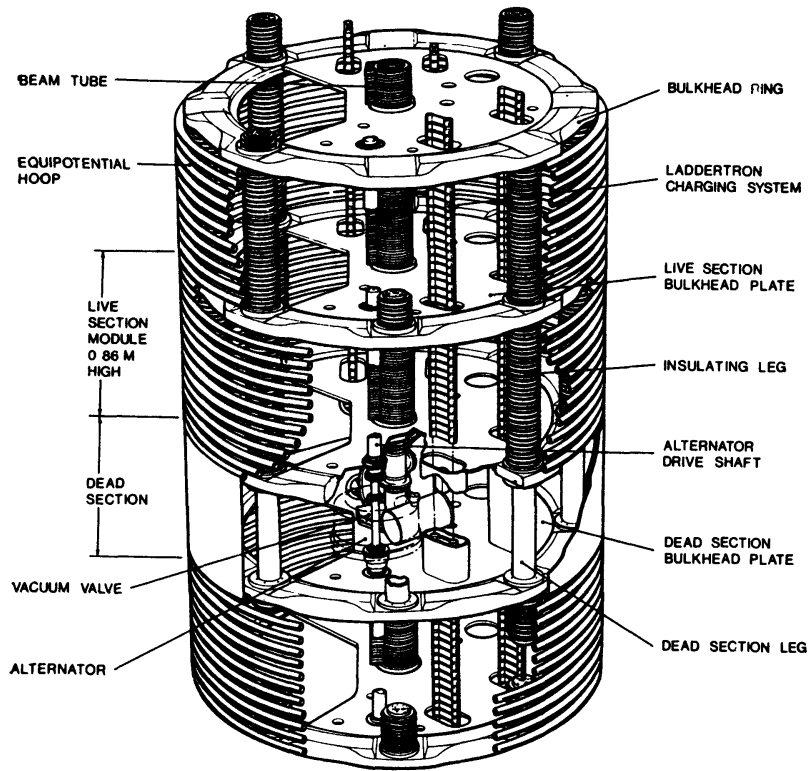

TYPICAL STACK SECTION INOICATING MAIN STRUCTURAL \& ELECTROSTATIC ELEMENTS

FiG. 3. - Drawing of column layout.

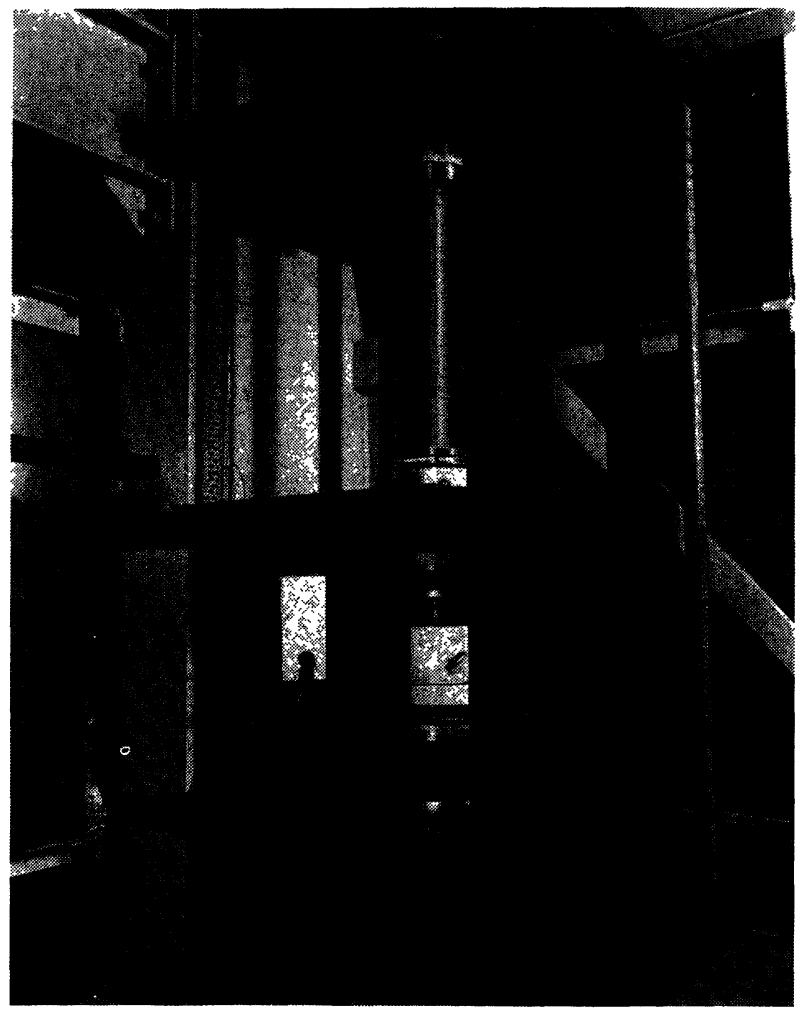

Fig. 4. - Test rig for drive shaft and alternators. an alternator and part of the drive shaft, and figure 5 shows the assembly of 3 live sections and one short dead section.

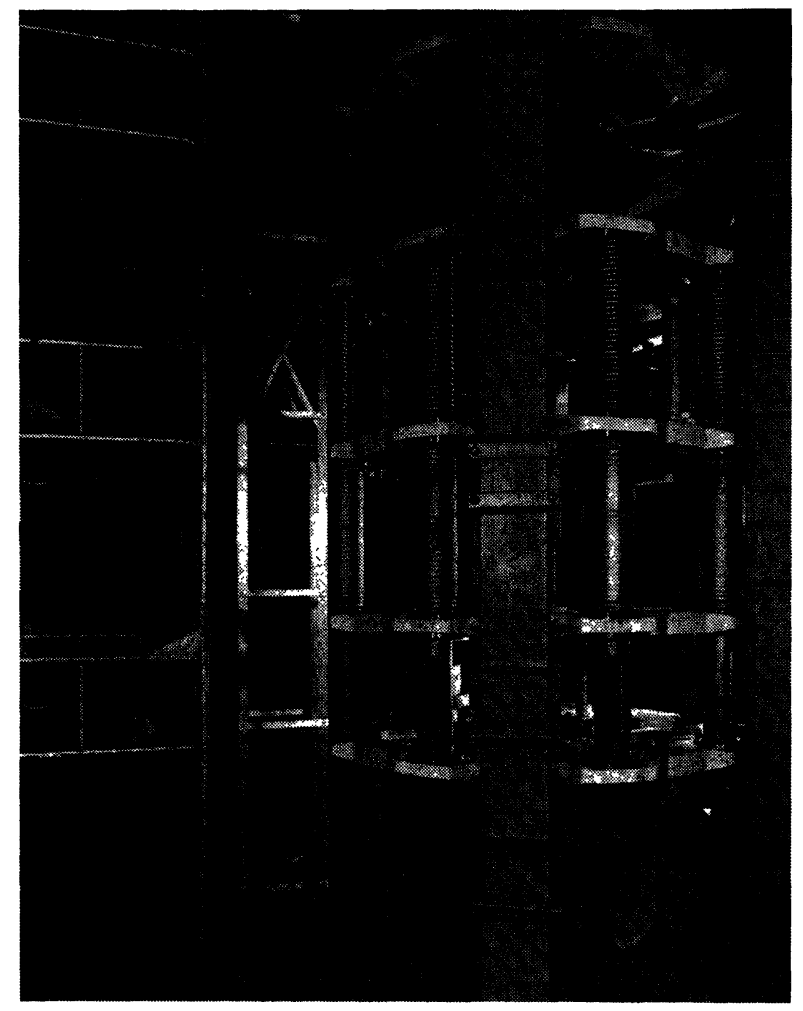

FIG. 5. - Assembly of 3 live sections and 1 short dead section.

The vacuum system is shown schematically in figure 6 . The ion pumps have specially strengthened casings for operation in the high pressure $\mathrm{SF}_{6}$. All the ion pumps, and the turbo-molecular pumps for use outside the pressure vessel, have been delivered, as have valves, power supplies and other components associated with the vacuum system. A cryopump, shown in figure 7 , for pumping stripper gas in the terminal has been developed, emphasis being on length of pumping time so as to ensure that gas does not have to be released into the accelerator tube. In passing I should mention that these and other components for use in the vessel are run for very long periods in a special test vessel containing high pressure $\mathrm{SF}_{6}$ to ensure that there are no problems with cooling or operation in high pressure gas.

Figure 8 shows a cutaway view of the accelerator. Assembly of the high voltage bun has started. The $500 \mathrm{kV}$ power supply has been fully tested and is most satisfactory, with a stability over 8 hours of \pm 2 parts in $10^{6}$. Two ion sources are available, as are all the power supplies for beam line components in the bun.

Following the beam line, the inflector magnet has been delivered and tested. The 3 magnet quadrupole lenses at the entrance to the vessel and the 15 quadrupoles inside the vessel are on site, tested and very satisfactory. Their power supplies are also tested. One 


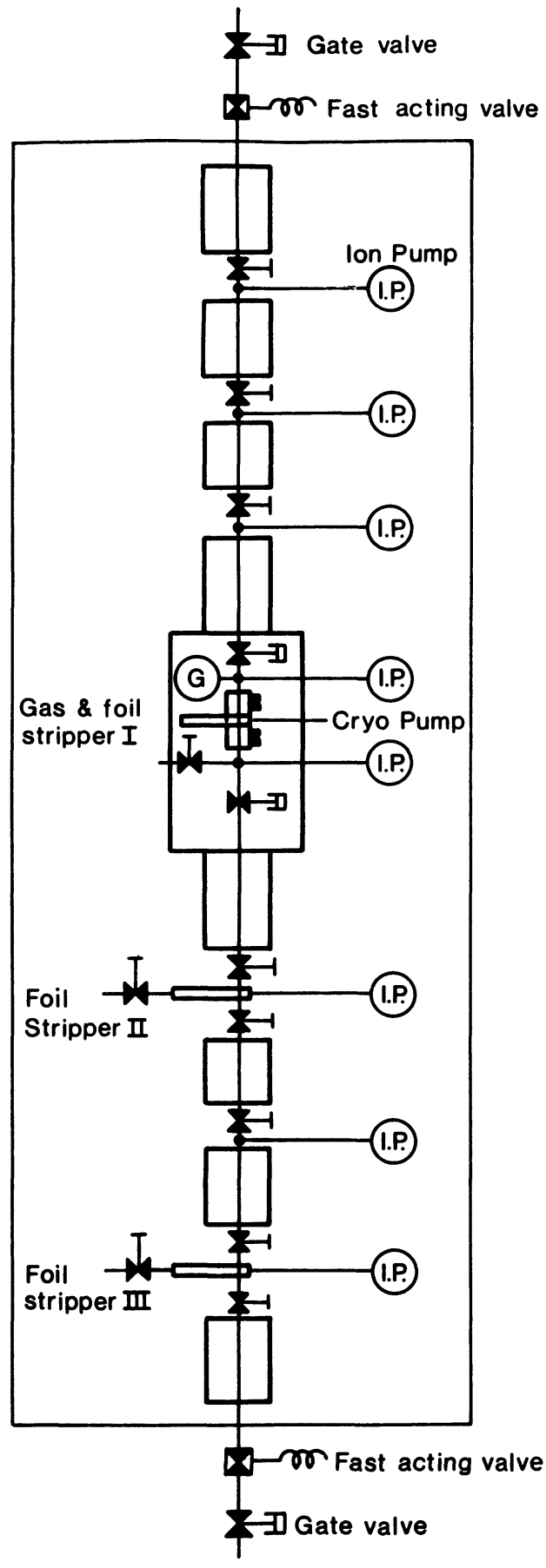

FIG. 6. - Schematic of vacuum system.

is seen in figure 9 in its double-screened crate. These have outputs variable over a range 100: 1 , and with a stability even at the bottom end of $\pm 0.01 \%$.

Returning to figure 8 , detailed design of the very complicated layouts in the dead sections and the terminals is largely complete, and many components are on order. Doors for the dead sections are being manufactured, and the curved end sections for the terminal have been delivered. The magnets for the offset quadrupole charge state selector are included in the delivery mentioned above. A foil changer holding 250 foils has been built and tested.

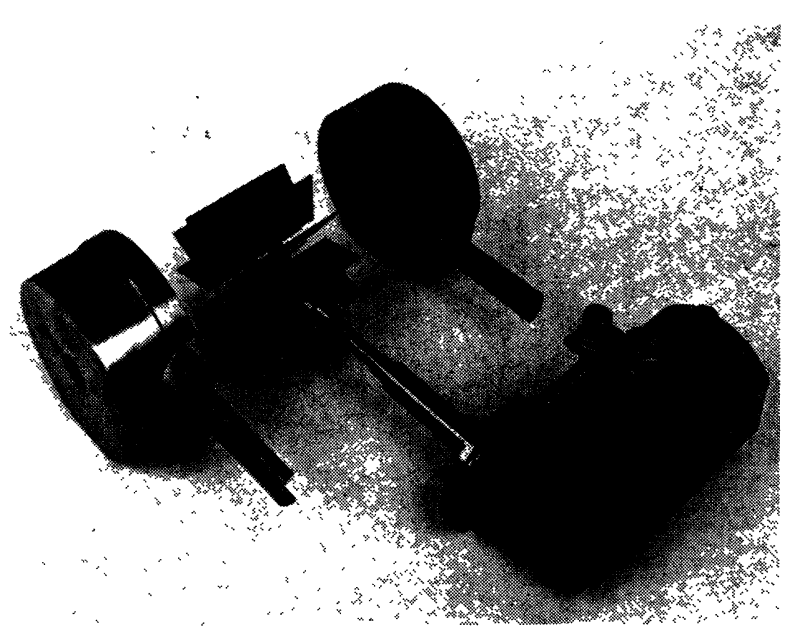

Fig. 7. - Photograph of cryopump.

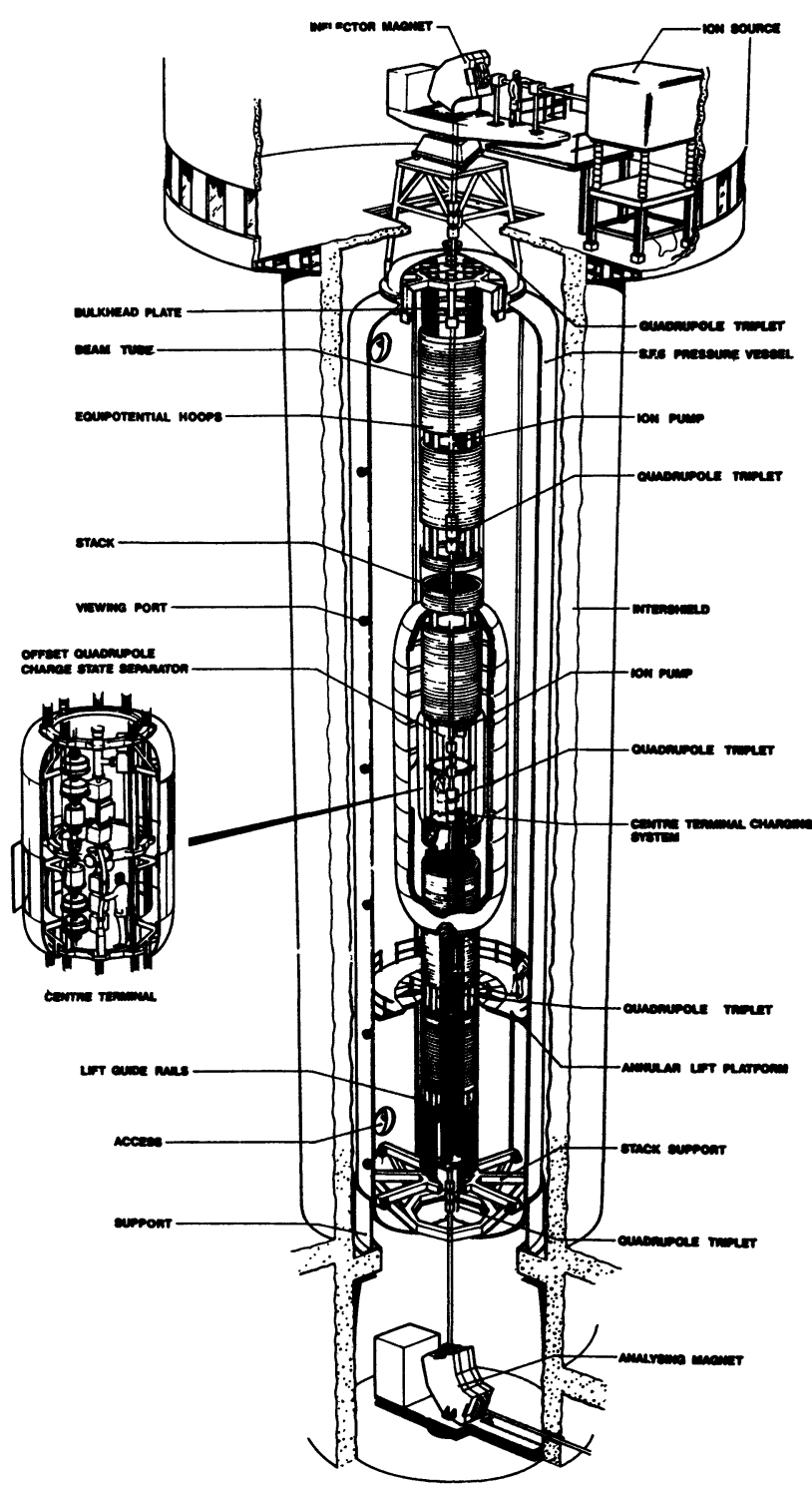

FIG. 8. - Cutaway drawing of accelerator. 


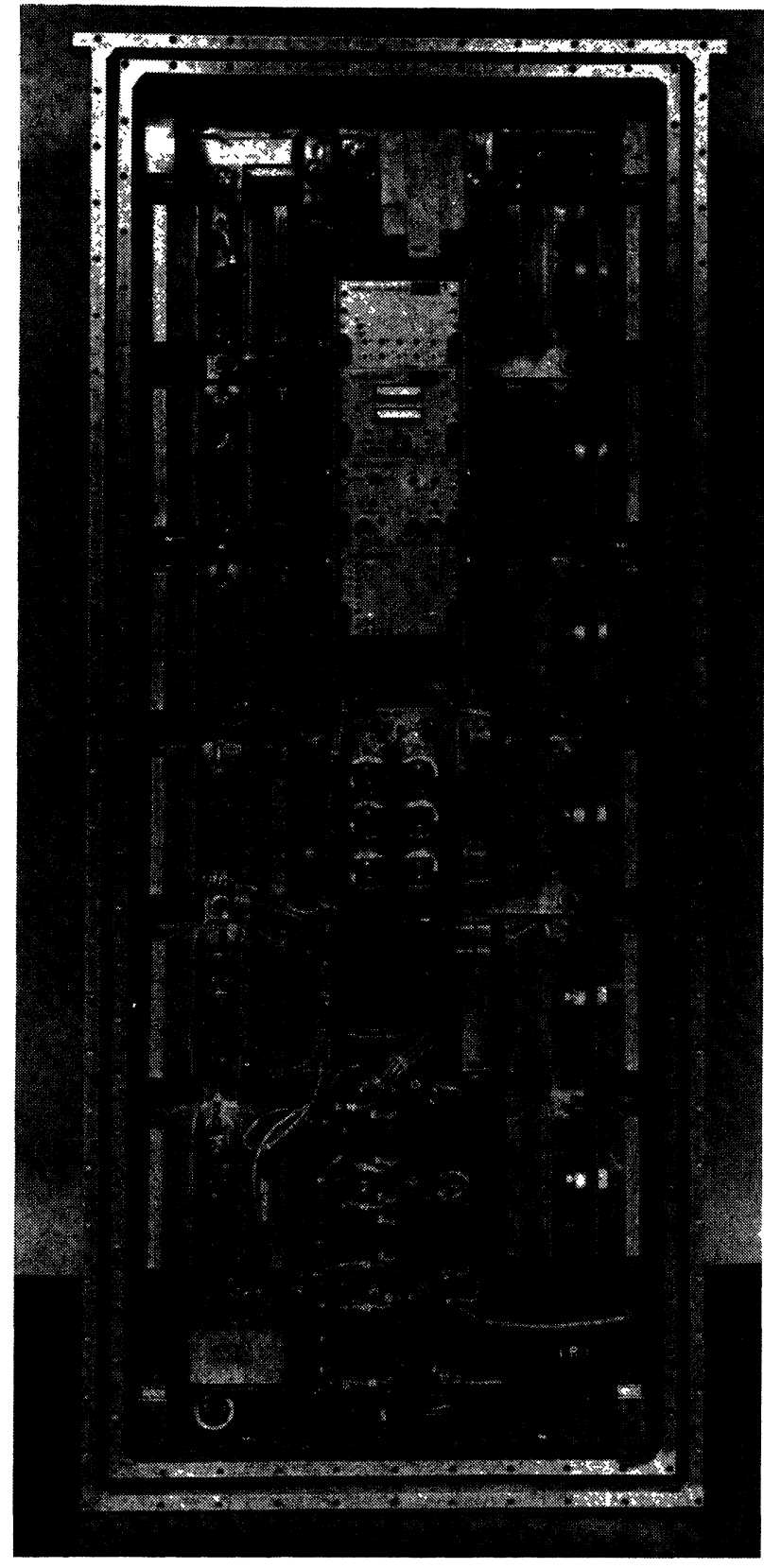

Fig. 9. - Photograph of power supply for a quadrupole magnet in double-screened crate.

The analyzing magnet is on site but is not yet satisfactory.

The annular lift platform and its driving gear has been delivered and installation will start shortly.

The circular crane at the top of the injector room has been installed. Early in 1978 the top of the pressure vessel will be removed, and column sections raised by the crane up the hoist well in the service tower and then lowered into position in the pressure vessel.

The design of the control system is virtually complete. A schematic is shown in figure 10. Digital serial data links are used throughout. All the computers have been on site for some time. The operating system is complete, and software preparation is well advan- ced. Much of the associated equipment, such as the Daresbury-developed colour TV displays and light pens, have been delivered. It is hoped that by the end of the year the injector will be completely controlled by the computer system.

Within the pressure vessel the digital serial data link is established by a $10 \mathrm{MHz}$ bandwidth infra-red light link. Three independent systems supply redundancy so that the accelerator can be kept operating even if some units fail. These are shown in figure 11. The first link passes through all dead sections and the centre terminal. The second link bypasses the short dead sections, but enables the long dead sections and the terminal to be controlled. The third link enables control of the terminal to be maintained if all else has failed. Rigorous testing of components over several years at voltages up to $10 \mathrm{MV}$ give confidence that the very careful screening which has been developed provides good protection against surge damage. All the double-screened crates are on site, most of the cards have been designed, and manufacture and assembly is under way. Most of the light link transmitting and receiving heads are already built.

In parallel with the construction work, a considerable programme of research and development continues to be devoted to the problems of electrostatic accelerators. Much of this will be covered in other papers to be presented to this conference. The basic facilities available include a 1.5 MV single-ended Van de Graaff, a Marx generator which produces pulses of amplitude up to $1 \mathrm{MV}$ and with rise times of a few nanoseconds, and the pilot machine shown in figure 12. It is built of the standard insulator legs developed for the NSF tandem. The column is 4 modules high, giving a length of about $3 \mathrm{~m}$, and the machine operates at up to about $10.5 \mathrm{MV}$. It has been run for many hundreds of hours with several tank sparks occurring per hour in order to test as rigorously as possible the various components. It is reassuring that the protective devices have successfully prevented any damage to the components. In figure 13 one sees the terminal with the cover removed. The laddertron is visible, together with $2.60 \mathrm{kV}$ supplies for its inductor and suppressor electrodes, and the double-screened control unit associated with the light link.

Figure 14 shows a plan of the building. On the right can be seen the 3 experimental areas. Discussions with the users on the main types of experimental equipment are well advanced. In the area at the top of the diagram it is planned to have an on-line isotope separator, plus a scattering chamber arrangement. In the middle area it is intended to have a large magnet spectrometer. The third area is to be a low background area and is reserved for $\gamma$-ray spectroscopy. Mention must also be made of the data acquisition system. The overall design has been established, 6 computers have already been delivered, and work is progressing on the associated hardware and software.

In conclusion, while a list .of references is not 
SYMBOS

ND MULTIPLEX SYSTEM UNKS LELECTRONUCS

ND SYSTEM CAMAC NTERFACE RING MAN CONNECTION

COMPUTER/ COMPUTER CAMAC

SERIAL DATA LUMKS

DIRECT MULTIWAY DATA \&

CONTROL PATHS (CAMAC)
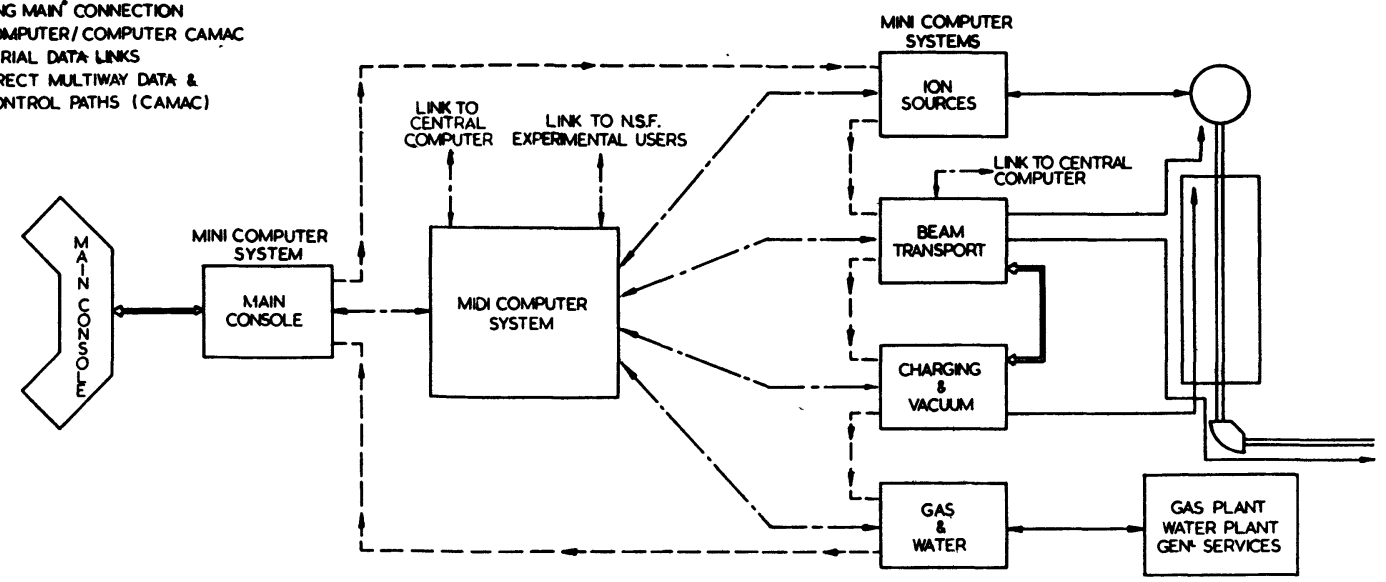

CONSOLE MINI COMPUTER

DISPLAY GENERATION

DTPLAT GER COMMUNCATION CONTROL

A/D SYSTEM "RING MAN" CONTROL

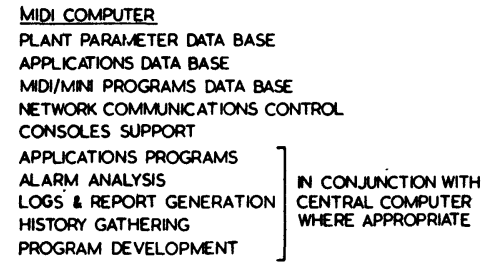

MIDI COMPUTER

R DATA BASE

MDI/MNN PROGRAMS DATA BASE

METWOAK COMMUNCATIONS CONTROL

TSOES SUPPORT

OGS \& REPORT GENE

HROGRAM DE WHERE APPROPRIATE

FIG. 10. - Schematic of control system
PLANT MINI COMPUTERS

OF PARAMETERS ON REOUEST ROUTINE PARAMETER SCANNING \& DATA REDUCTION AUTOMATIC FAST RESPONSE CONTRO

PLANT SEQUENGING

AREA CONSOLE CONTRO

MDI FALUPE BACKUP

COMMUNICATIONS CONTROL

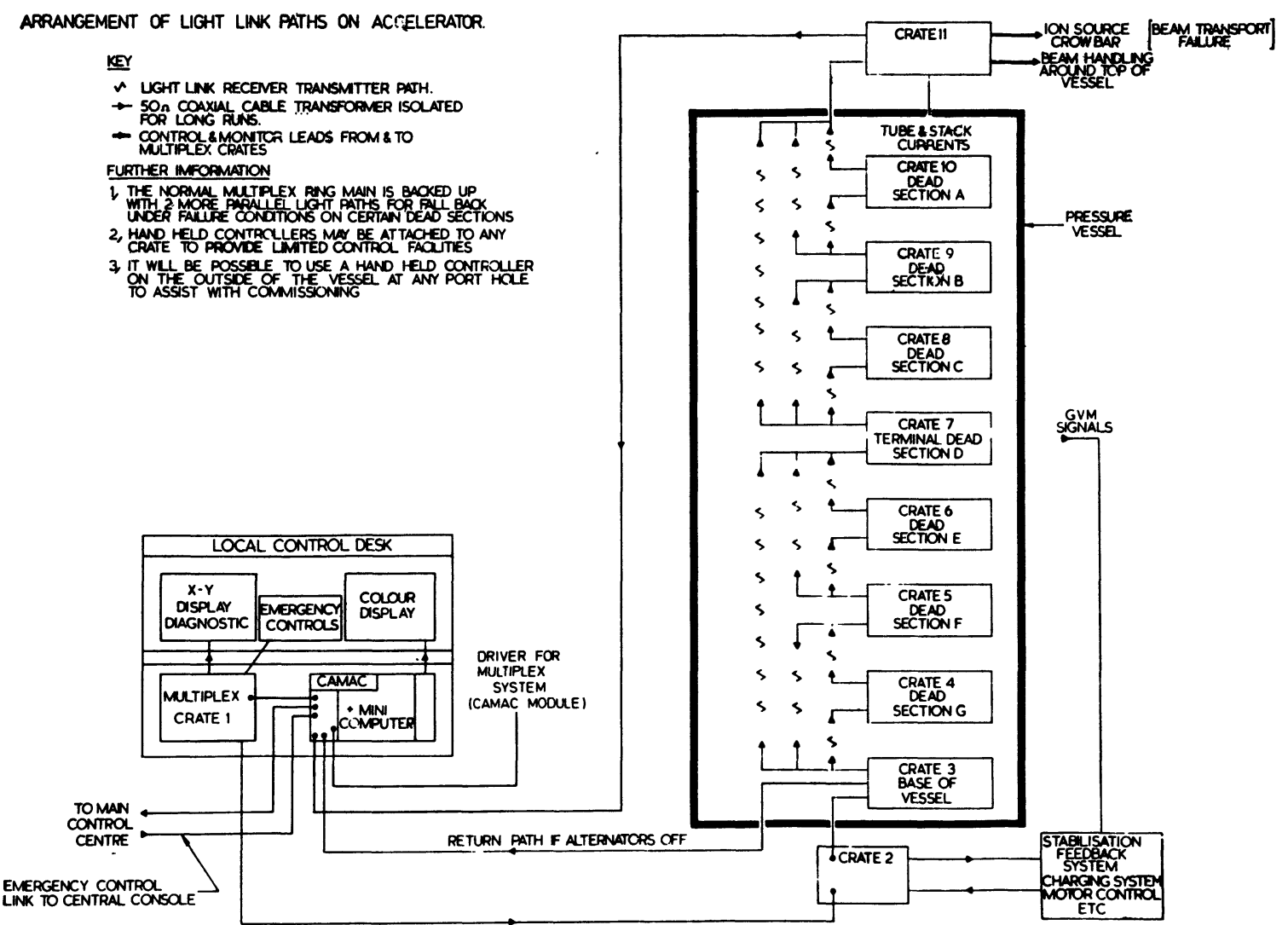

Fig. 11. - Schematic of light link systems in the pressure vessel. 


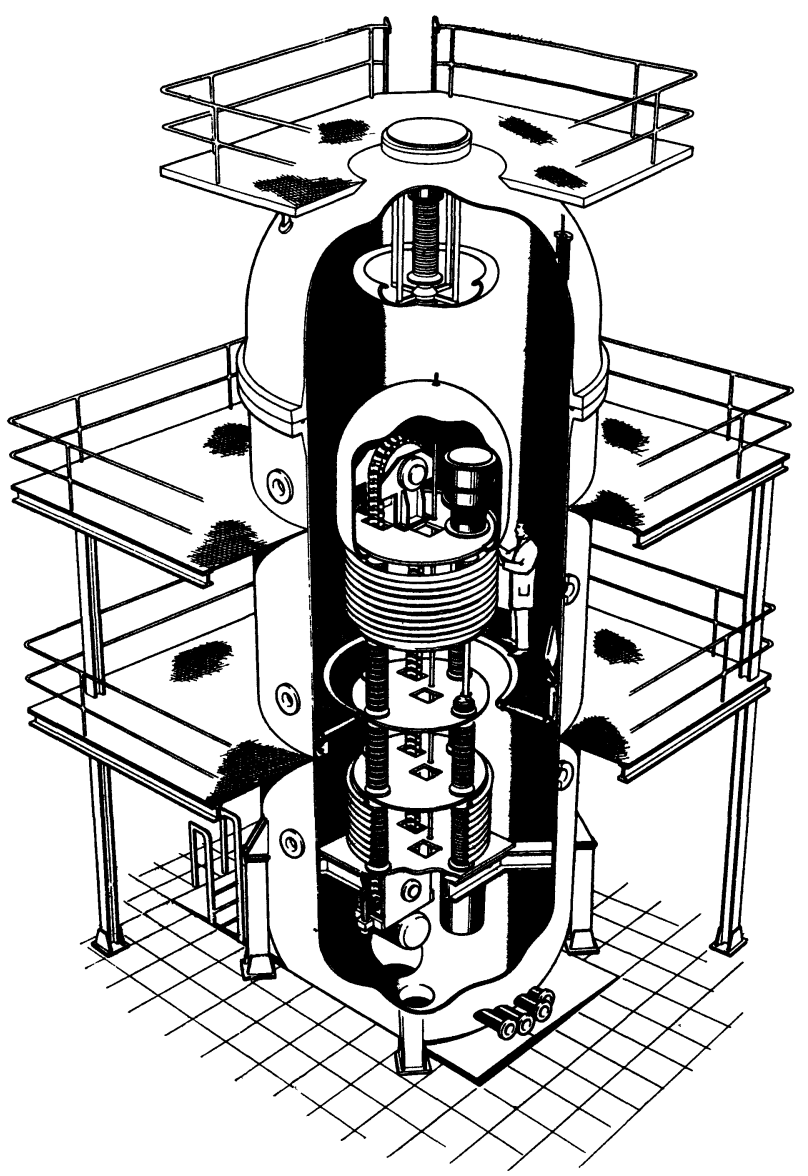

FIG. 12. - Drawing of $10 \mathrm{MV}$ pilot machine. appended to this paper, the R. \& D. programme has led to the publication of over 50 reports relating to the technology of electrostatic accelerators, and these are available to those interested.

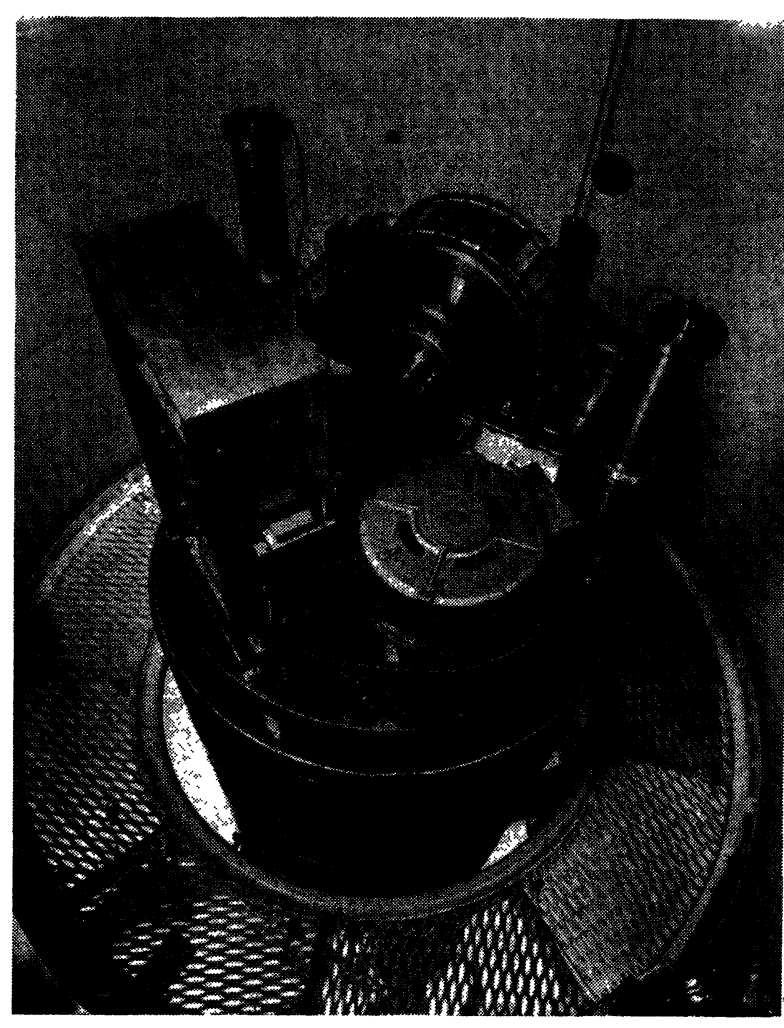

FIG. 13. - Photograph of pilot machine terminal.

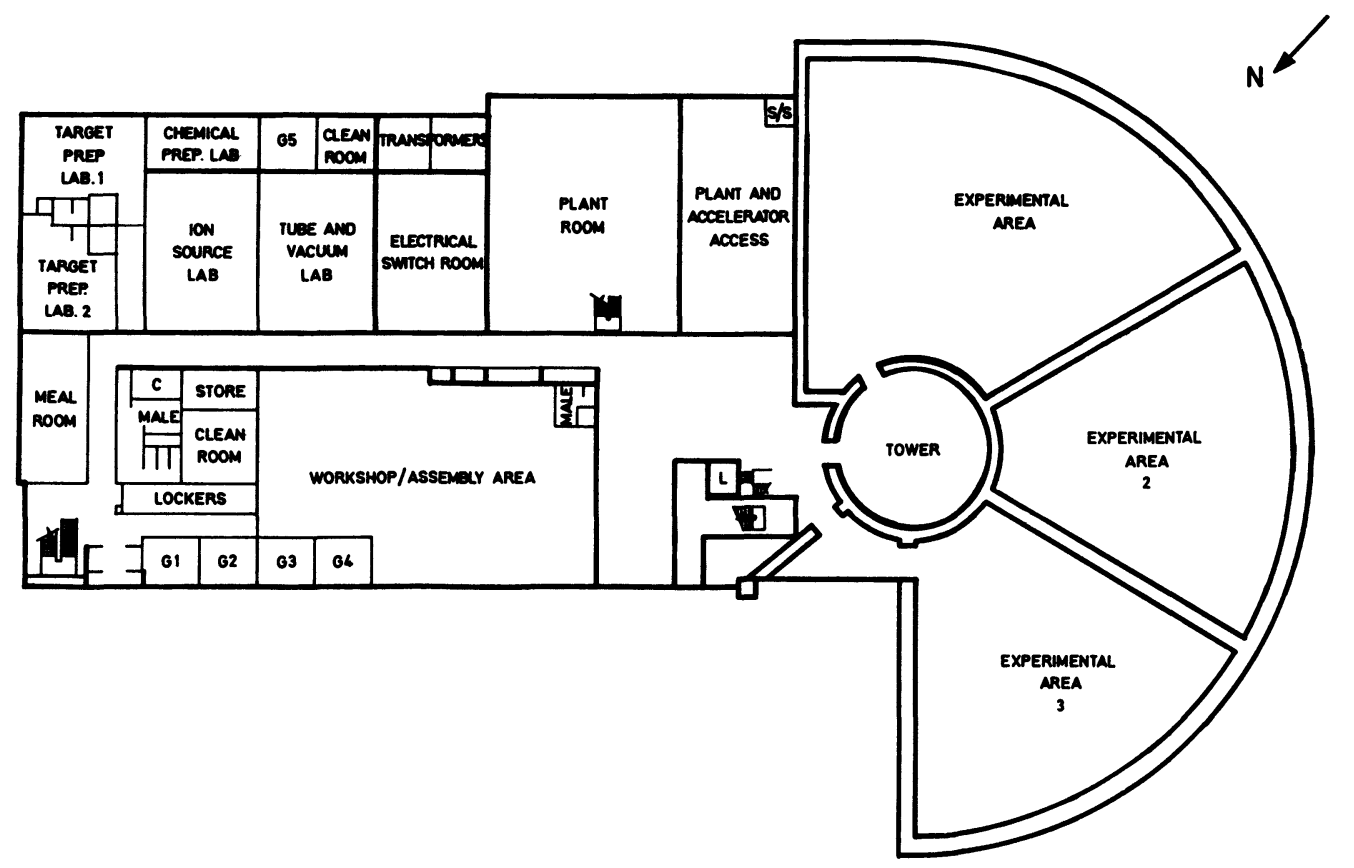

KEY

C CLEANERS

L LIFT

S/S SPIRAL STAIRS
NUCLEAR STRUCTURE FACILITY GROUND FLOOR

SCALE IN METRES \begin{tabular}{lllll}
0 & 5 & 10 & 20 & 30 \\
\hline
\end{tabular}

